\title{
DeVELOPMENT OF SOFt SKILLS FROM OUT-OF-SCHOOL EXPERIENCES In PERU. LeARnings From Non-Profit Organizations' Activities in Public Schools in Lima
}

\author{
Carla lizette Mendoza Egúsquiza* \\ University of Manchester \\ carla.mendoza.egu@gmail.com
}

Received: 14/5/2021 Accepted: 21/8/2021

doi: https://doi.org/10.26439/contratexto2021.n036.5193

ABSTRACT. This research aimed to examine the enhancement of soft skills in public education in Peru through analysing non-profit organisations' techniques at the school level. The objectives were (a)To understand how the quality of education in Peruvian public schools assures the development of soft skills, (b)To explore the potential of non-profit organisations in supporting the development of soft skills in public schools. Interviews with three non-profit organisations and a government official, alongside reports, were analysed based on an OECD model.

The findings include government initiatives that indirectly develop soft skills, but management issues might lead to teacher-centred rather than student-centred methodologies, deterring skills development. Unfriendly environments characterise vulnerable areas for skills development; non-profits become supportive disruptive spaces to cultivate values, ethics, and skills. The discourse analysis concludes that, despite their small scope, they mainly develop collaboration and task performance skills, impacting career decisions, families and communities.

Non-profits employ a playful and concrete methodology that fosters the development of soft skills, but which is difficult to implement in public schools due to a lack of resources and school management. Further research should explore non-profits' impact on skills development. This study is a pioneer in this field in LATAM.

KEYWORDS: soft skills / NGO / quality education

\footnotetext{
* Magíster en Ciencias Sociales en Cambio Organizacional y Desarrollo por la University of Manchester, Reino Unido (véase: https://orcid.org/0000-0003-0111-4766)
} 


\section{DESARROLLO DE HABILIDADES BLANDAS A PARTIR DE EXPERIENCIAS EXTRAESCOLARES EN PERÚ. APRENDIZAJES DE LAS ACTIVIDADES DE ORGANIZACIONES SIN FINES DE LUCRO EN ESCUELAS PÚBLICAS DE LIMA}

RESUMEN. El objeto de estudio fue examinar la mejora de las habilidades sociales (HH. SS.) en la educación pública en el Perú a través del análisis de las técnicas de las organizaciones sin ánimo de lucro (OSAL) a nivel escolar. Los objetivos fueron (a) comprender cómo la calidad de la educación en las escuelas públicas peruanas asegura el desarrollo de HH. SS., (b) explorar el potencial de las OSAL para apoyar el desarrollo de HH. SS. en las escuelas públicas. Utilizando un modelo de la OCDE, se analizaron informes y entrevistas con tres OSAL y un funcionario del gobierno.

Los hallazgos incluyen iniciativas gubernamentales que indirectamente desarrollan HH. SS., pero problemas de gestión por una metodología que prioriza a los profesores en lugar de los alumnos desalientan este desarrollo. Las áreas vulnerables suelen ser entornos hostiles para el desarrollo de habilidades, transformando las OSAL en espacios disruptivos complementarios para cultivar valores, ética y habilidades. El análisis del discurso concluye que, a pesar del corto alcance, principalmente desarrollan HH. SS. relacionadas con la colaboración y el desempeño de tareas, impactando en las decisiones vocacionales, en las familias y comunidades.

Las OSAL emplean una metodología lúdica y concreta que fomenta el desarrollo de HH. SS., pero es difícil de implementar en escuelas públicas, debido a la falta de gestión y recursos. Futuras investigaciones deberían explorar el impacto de las OSAL en el desarrollo de habilidades. Este estudio es pionero en LATAM.

PALABRAS CLAVE: habilidades blandas / ONG / calidad educativa 


\section{DESENVOLVIMENTO DE SKILLS SOCIAIS A PARTIR DE EXPERIÊNCIAS FORA DA ESCOLA NO PERU: APRENDIZADOS COM ATIVIDADES DE ORGANIZAÇÕES SEM FINS LUCRATIVOS EM ESCOLAS PÚBLICAS EM LIMA}

RESUMO. Esta pesquisa teve como objetivo examinar o a melhoria das skills sociais na educação pública no Peru, analisar o trabalho das organizações sem fins lucrativos (OSFL) nas escolas. Os objetivos eram (a)Compreender como a qualidade da educação em escolas públicas no Peru garante o desenvolvimento de skills sociais, (b)Explorar o potencial de OSFL no apoio ao desenvolvimento de skills sociais em escolas públicas. Usando um modelo da OCDE, foram analisados relatórios e entrevistas com três OSFL e um funcionário do governo.

Os resultados incluem iniciativas governamentais que indiretamente desenvolvem skills sociais, mas questões de gestão levam a metodologias que parecem ser centradas no professor em vez de centradas no aluno, impedindo o desenvolvimento de habilidades. As áreas vulneráveis são caracterizadas por ambientes hostis para o desenvolvimento de habilidades, OSFL tornam-se espaços disruptivos complementares para cultivar valores, ética e habilidades. Análise de discurso conclui que, apesar do escopo curto, desenvolvem principalmente habilidades relacionadas à Colaboração e Desempenho de Tarefas, impactando nas decisões vocacionais, famílias e comunidades.

As OSFL empregam uma metodologia lúdica e concreta que fomenta o desenvolvimento de skills sociais, mas de difícil implementação na escola pública, devido à falta de gestão e recursos. Pesquisas futuras devem explorar o impacto dos OSFL no desenvolvimento de habilidades. Este estudo é pioneiro na LATAM.

PALAVRAS-CHAVE: skills sociais / ONG / qualidade educacional 


\section{INTRODUCTION}

\section{Education quality}

LATAM lands at the lowest positions in educational assessments and holds one of the lowest GDP growth rates when combining decades since the 1960's, contrasting with higher-performing countries in education whose GDP increased further during the same time. Despite several factors affect this correlation, and educational reforms could take decades to show results, the link between quality education and national development arises (Hanushek \& Woessmann, 2007; Hanushek \& Woessmann, 2015). Quality involves educating citizens who contribute to the development of communities and countries through different types of skills, including socioemotional skills (Tawil et al., 2012). Figure 1 introduces the Framework for Understanding Education Quality (FEQ) which exhibits the factors that impact quality in education; Context, Learner's Characteristics, Enabling Inputs, Teaching and Learning, and Outcomes. FEQ illustrates education as a dynamic process with a cultural, social, and political side, providing an input-process-output path (Tawil et al., 2012).

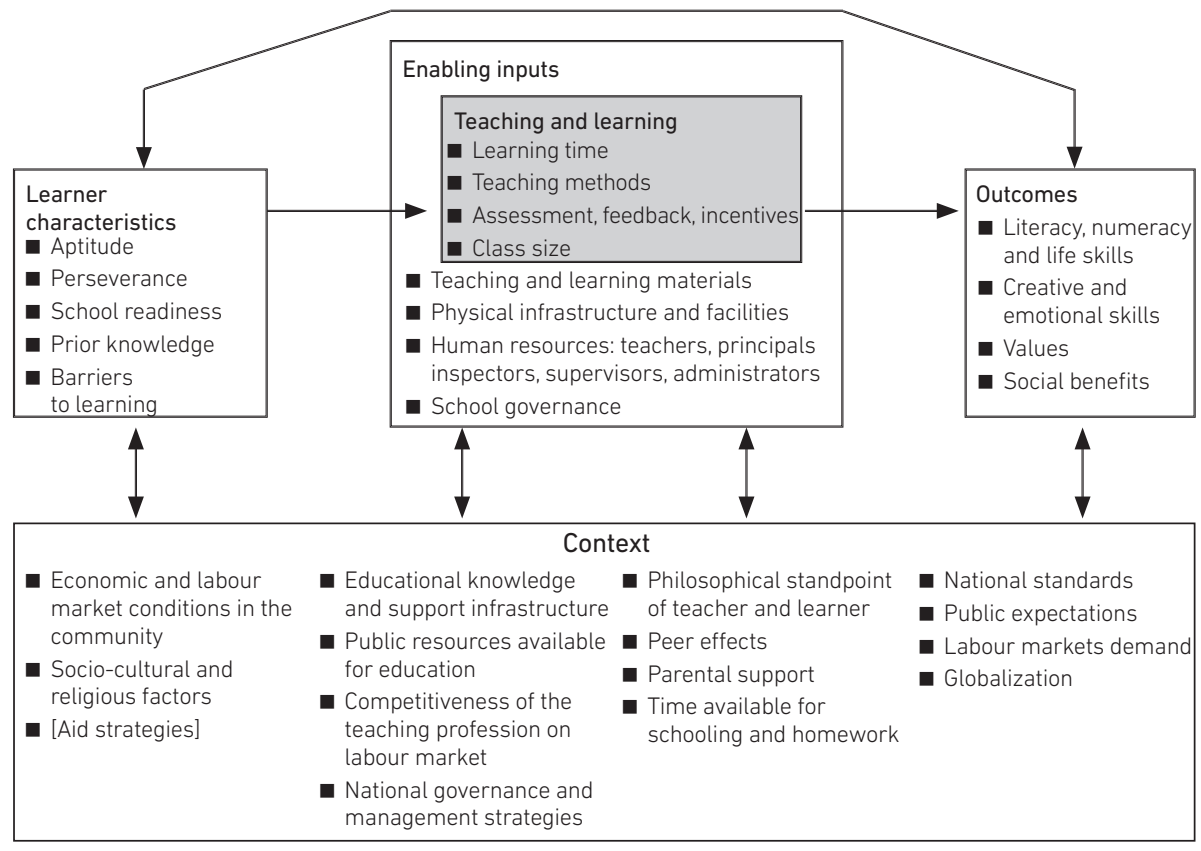

Figure 1. A Framework for understanding education quality (FEQ)

Source: UNESCO (2015) 
The Context involves the influence and value provided by society to education, economy, and politics. The Learner's Characteristics consist of people's capacities, households, and experiences, showing background differences and how these create or reduce inequalities. The Enabling Inputs relates to school management and community relationship, comprising resources and governance. Teaching and Learning considers everything related to the learning experience, including teaching style and assessments. The Outcomes are the results of the educational process, usually measured in literacy and numeracy skills, at a wider level, with the impact in development (Unesco, 2005).

FEQ illustrates the importance of policies, teachers, buildings, management, and families in quality, alongside their synergy, exhibiting the diversity and responsibility of stakeholders. It might provide a national analysis and a diagnosis, which is necessary to avoid drawbacks on effectiveness, deterring quality, and impacting future generations (Oded, 2011).

In developing Context, the challenge is to improve the quality of education coping with problems such as grade repetitions, teacher absenteeism, or early school leaving. A common flaw is a lack of management which causes budget distortions, low incentives for teachers and inaccurate curricula (Glewwe \& Kremer, 2006). Teachers could receive low salaries because of the number of professionals needed to supply the market. This might signify hiring teachers who could not be as trained as their counterparts in developed countries or increment the pupil-teacher ratio. Impacted by low budgets, families might need to cover additional expenses. The Learner's Characteristics can be too diverse and heterogeneous to fit a one-size-for-all national curriculum, increasing drawbacks such as language barriers or extended distances to commute to school in rural areas (Glewwe \& Kremer, 2006). These inputs create inequalities, leaving students in a process with disadvantages, which in the long-term, affect social mobility and economic development (Oded, 2011). This analysis raises the question that, if governments are already dealing with several barriers and are delivering low performance in international assessments, how can they assure quality in what is more difficult to measure, such as soft skills?

\section{Soft Skills}

Soft skills can be defined as: "individual capacities that can be (a)manifested in consistent patterns of thoughts, feelings, and behaviours, (b)developed through formal and informal learning experiences, and (c)important drivers of socioeconomic outcomes throughout the individual's life" (OECD, 2015, p. 35). The first statement drives to a complex, difficult-to-measure psychological side. The second displays that soft skills can be fostered outside schools, highlighting the responsibility of varied stakeholders. The last statement was explained in the previous section. 
Research remains limited, focused on developed countries, particularly vulnerable groups (West et al., 2016). A lack of consensus on a common framework to measure skills deters the possibility of creating a cross-country analysis (Kerstetter, 2016; Jayaram \& Engmann, 2017). The complexity increases with cultural bias; meanings and perceptions can change within cultures, within the same country, and in different groups (Nichols, 2017). The Big Five dimensions, a popular framework, studies personality traits that can be shaped throughout life and might impact behaviours, affecting educational attainment, health, and employment outcomes (Humphries \& Kosse, 2017; Kankaraš \& Suarez-Alvarez, 2019).

Based on OECD studies, a tentative framework is illustrated in Figure 2, introducing a skills development model throughout life stages and differences between Cognitive skills, Mixed skills, and Socio-emotional skills. The first ones are the traditional skills measured in international assessments, namely literacy and numeracy; the second mixed category includes cognitive and socioemotional skills that are especially important to support the growth of the other two categories; and the third is based on the Big Five personality traits. This last group is the focus of the research because it describes abilities fostered in formal and informal environments. The Big Five model aims to understand human personality by identifying five dimensions related to distinctive sets of behaviours, thoughts, and feelings. Research confirms its applicability for children and teenagers and throughout life, as the sub-domains provide an overview of social and emotional skills development (Kankaraš \& Suarez-Alvarez, 2019).

The model confirms the importance of each stakeholder's role and the skills that should flourish per stage, evolving throughout the individual's growth. It acknowledges the impact skills hold in education, earnings, health, and crime tendency, describing the desired achievements by life stage (Kankaraš \& Suarez-Alvarez, 2019).

The framework is complemented with the OECD's 15 Socioemotional Skills, listed in Appendix 1. The Big Five Personality traits were correlated with skills as followes: Openness, Agreeableness, Emotional Stability, Conscientiousness, and Extraversion; to Open-mindedness, Collaboration, Emotional Regulation, Task Performance, and Engaging with others, respectively. These traits were preferred as they are a standard theory for skills research, applicable for varied cultures, offering a detailed description of behaviours (McCrae \& Terracciano, 2005), being methodological easier to understand to the non-research community, such as teachers and parents. 

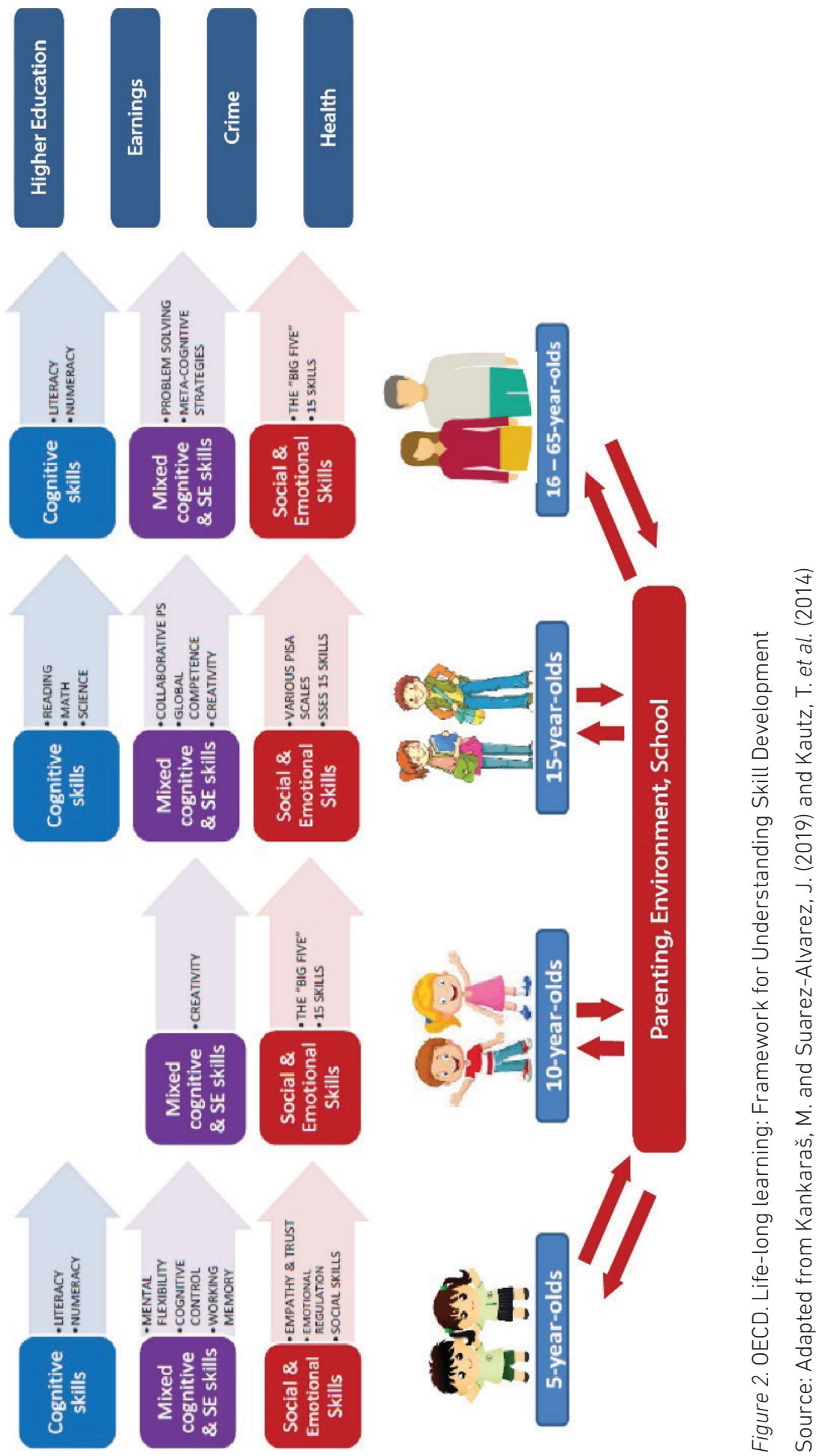
Regarding the measurement of socio-emotional skills, the main techniques used in studies are Likert-system questionnaires targeting students. As these are affected by cultural bias, researchers use anchoring vignettes to avoid it, providing a specific context in the questions to detach the students or other agents, such as parents and teachers, from their own context. However, as skills measurement tends not to influence the students' grades, they might not complete surveys as accurately or responsibly as others (Primi et al., 2016). As for techniques, studies confirm the potential of extracurricular courses, peer an parental support, summer courses, placements, and problem-solving methodologies as means to enhance skills (Kautz et al., 2014). Socioemotional skills exhibit the development of more skills; students with higher extracurricular activities tend to achieve positive results without regard to their background (Lleras, 2008; Jagannathan et al., 2019).

Difficulties in measurement and development techniques increase in developing countries, where informal economies are more prevalent (James et al., 2012). Informal workers require skills to be independent but lack access to training opportunities and usually hold a low education level (Jayaram \& Engmann, 2017). Dropout rates signify that a portion of the workforce will join with school-level knowledge (Wang et al., 2016, Namuddu et al., 2017). Governments address these concerns with strategies, such as decentralisation, the drawback of which is the teaching quality, as incentives and requirements could be less exigent than in central areas (Di Gropello, 2006). Therefore, the private and non-profit sectors become important actors. NGOs usually hold a projectbased performance with a short-term scope, being especially important in unreachable areas with low government presence. These projects could influence policy designs. (Banks et al., 2015; Bebbington, 1997; Namuddu et al., 2017). However, local NGOs endure limited scope and lack of sustainability. The funding needed might lead to bias in their assessments, displaying positive results (Rose, 2009).

\section{Education in Peru}

Peru has had one of the highest and steadiest economic growths over the last couple of decades. The country has reduced poverty, allowing social mobility towards the middle class (World Bank, n.d), translating into more people affording private education. This development was not accompanied by educational attainment, as in 2012, Peru landed last in the PISA test (OECD, 2014). Although the nation improved in the following assessments, it exhibits the greatest inequality between advantaged and disadvantaged students in LATAM (Schleicher, 2019). Studies show that private or public education, family income, and gender can greatly predefine educational attainment (Saavedra \& Gutierrez, 2020). Nevertheless, private schools in low-income areas might deliver lower results than public ones. The same cannot be said for high-income areas, as the higher the institution fees, the higher the attainment. (Marcos \& Vasquez, 2018). 
The government implemented reforms targeting three key areas: management, infrastructure, and quality teaching. The first includes relief of administrative duties to schools' principals, adding supportive positions. An accreditation system was enforced in private higher education to assure quality standards, but this has not been implemented at the school level (Darcourt et al., 2020). One project performed is Full School Day (JEC in Spanish), reaching almost $14 \%$ of public schools (JEC, n.d). Its characteristics include longer school days, additional pedagogical assistance, and strengthening management, infrastructure, and IT support. The extra school time is dedicated to enhancing socio-emotional and technical skills, aiming to increase employability (Sanchez \& Favara, 2019). JEC emulates a private-school management style and delivers better outcomes than other public schools (Marcos \& Vásquez, 2018). Another project is COAR (High-Performance Schools), dedicated to outstanding students, targeting skills development based on international standards (MINEDU, n.d.b). Regarding the infrastructure, some institutions lack maintenance and basic services, which was addressed by creating a specialised institution.

In quality teaching, low salaries, resources, qualifications, and social recognition have deterred teaching performance. Peruvian teachers earn a third in proportion to their wages 50 years ago, being one of the lowest paid in the region (Mizala \& Nopo, 2016), generating some teachers seek other income sources reducing time to develop other activities (Osorio et al., 2018). Applications decreased in the last decades, causing the average age to land at 40 years by 2012 (Saavedra \& Gutierrez, 2020). Older teachers could be less open to innovation or technological changes, adapting slower to new methodologies. To address these challenges, the institution improved the assessment system, the professional development, and the In-service teacher preparation, modifying the career towards performance and assessments instead of the number of years of service (Osorio et al., 2018; Minedu, nd. a). However, this has been accompanied by political controversy and manifestations. Administrations have not necessarily continued policies, leading to short-term implementations and potential initiatives left aside (Osorio et al., 2018).

A study showed that parents identify good quality public schools with stricter norms and policies, supportive teachers, principals' leadership, and other characteristics, rather than outcomes. Parents restrained their quality expectations as they place less importance on performance (World Bank, 2007). Hence, if parents are satisfied with lower results or hold lower expectations, they are less likely to demand higher quality. This perception in society could affect the value given to education. As education is perceived as a public service, school governance might lack parental involvement, exhibited in APAFA participation. This is a parental group in every school that aims to cover institutional drawbacks. Despite their positive impact, mostly the same group of parents comprise their local organisations, and few tend to actively participate in management activities (El Comercio, 2014). 
Allocating public resources might affect equality, particularly within indigenous and rural populations, where education usually disregards local languages. Education in Quechua, the second spoken language, has exhibited higher attainment (Hynsjöa \& Damon, 2016; Osorio et al., 2018), but it continues to be a concern (Cortina, 2016). The lack of quality and equity results in around $23 \%$ of Peruvian continuing into higher education and $15 \%$ into technical studies (INEI, 2019b). Higher education becomes relevant in the labour market, contrasting with developed countries (Castro et al., 2016). Higher education access is influenced by family finance, parental background, socioeconomic status, and socioemotional skills (Cueto, 2016).

Regarding the learning experience, a new National Curriculum has been implemented since 2018 (Osorio et al., 2018). Figure 3 overlaps the curriculum's desired profiles and the OECD's skills model. Although the profiles are not explicit with soft skills, they expect behaviours and attitudes relatable to the OECD framework, such as "The student interprets reality and reaches decisions from mathematical knowledge which contributes to his/her context" (MINEDU, 2017, pp. 34), which would involve persistence, responsibility, creativity, assertiveness, and curiosity. This profile is subdivided into competencies, which includes a Problem-Solving based methodology at the high school level (MINEDU, 2016). Developing soft skills indirectly is not new, albeit, as learning objectives are not accomplished, then indirect skills are unlikely developed either.

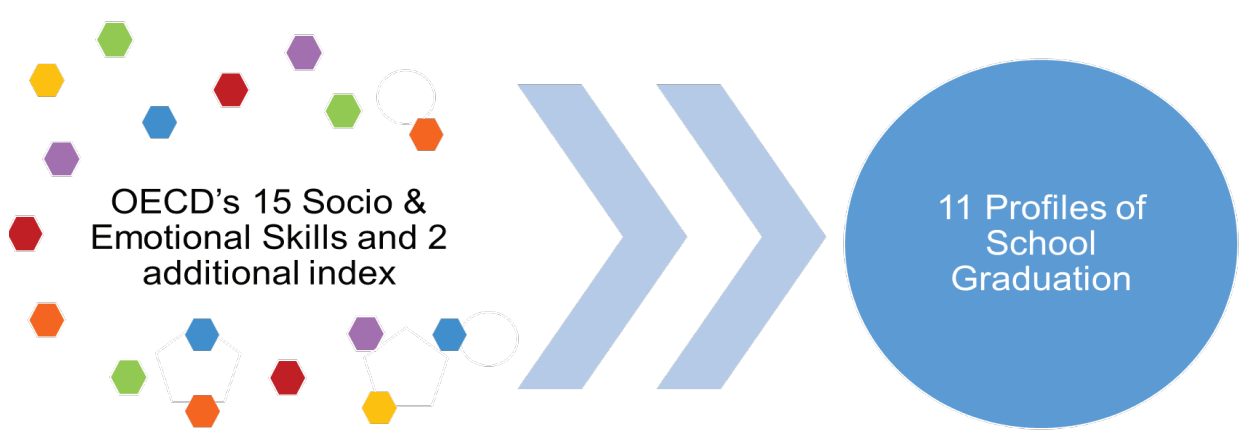

Figure 3. Socioemotional Skills and Peruvian Profiles of School Graduation

Own elaboration

Reforms appear to lead to positive outcomes and have signified an increment in the budget to almost double in a decade (MINEDU, 2018). While investment is still lower than average in LATAM, it exhibits the government's improvement but will take years for changes to show their impact (Saavedra \& Gutierrez, 2020).

Other actors in society support educational development. The private sector holds social responsibility projects. Meanwhile, the non-profit sector composes diverse 
projects, such as Fe y Alegria (Faith and Joy) schools, which are partially public-funded and represent a different management style and curriculum option (Portocarrero et al., 2002), and Aprendo Contigo (I Learn with you), which supports the education of hospitalized children (Aprendo Contigo, n.d). Albeit their impact would be shorter in scope and term than government, their presence could influence policy design. In Peru, non-profits operate an average of four years minimum, being education the area where a third of them work. Not all are registered as NGOs, but these are mainly managed by volunteers. Common drawbacks shared are the lack of funding, resources and volunteers' commitment. Around $60 \%$ of them manage a defined budget, self-funded or, to a lesser extent, funded by external actors (MIMP, n.d).

\section{METHODOLOGY}

\section{Research Design}

The literature exhibits certain gaps. The most relevant one is the absence of soft skills studies and public education in developing context, especially in Peru. This gap also includes a lack of studies about basic education, soft skills, and development, which can be explained by the difficulty of measuring them, especially in a variety of settings. However, a considerable number of studies were found on quality in education.

An analysis of the discourse revealed the research targets techniques used by nonprofits that can be useful when strengthening soft skills in the public system, and the feasibility of expanding their scope, which has not been studied in the Peruvian context. This study was performed on qualitative techniques, including semi-structured in-depth interviews and secondary data analysis, based on the research design in Table 1.

The literature review has provided two frameworks; the FEQ model, which assesses quality in education and would be applied with the first research question, and the OECD's model, which appraises soft skills and is being used on a study comparing international settings. This second model was the theoretical basis for the second research question.

The participants were selected using non-probabilistic sampling methods, including convenience and snowball techniques (Walliman, 2011), and their profiles are detailed in Table 2. Meanwhile, the non-profits exhibited in Table 3 were chosen based on their activities before March 2020 and were required to operate in public schools located in vulnerable areas in Lima. This city is occupied by a third of the total population (INEI, 2019a) and experiences more volunteer activities. A decisive variable for determining the non-profits was that developing soft skills was explicitly announced in their programmes. Some of the keywords found were "soft skills", "life skills" or "develop capacities" and these were targeted by workshops. Based on the literature review, having one-to-one interaction with the children was essential for selecting the organisation. 
Table 1

Research Design

\begin{tabular}{|c|c|c|c|}
\hline Aim & Objective & Research question & Methodology \\
\hline \multirow{3}{*}{$\begin{array}{l}\text { To examine the } \\
\text { enhancement } \\
\text { of soft skills in } \\
\text { public education } \\
\text { in Peru through } \\
\text { analysing } \\
\text { non-profit } \\
\text { organisations' } \\
\text { techniques at the } \\
\text { school level }\end{array}$} & $\begin{array}{l}\text { To understand how the } \\
\text { quality of education in public } \\
\text { schools in Peru assures the } \\
\text { development of soft skills }\end{array}$ & $\begin{array}{l}\text { What is the quality of soft } \\
\text { skills education in public } \\
\text { schools? }\end{array}$ & $\begin{array}{l}\text { Primary data: } \\
\text { Interview }\end{array}$ \\
\hline & $\begin{array}{l}\text { To explore the potential of } \\
\text { non-profit organisations in } \\
\text { supporting the development } \\
\text { of soft skills in public schools. }\end{array}$ & $\begin{array}{l}\text { What is the contribution of } \\
\text { non-profit organisations } \\
\text { to the development of } \\
\text { soft skills in the public } \\
\text { education system? }\end{array}$ & $\begin{array}{l}\text { Primary data: } \\
\text { Interview } \\
\text { Secondary data: Non- } \\
\text { profit organisations' } \\
\text { Report Review }\end{array}$ \\
\hline & & $\begin{array}{l}\text { What is the feasibility } \\
\text { of adapting non-profit } \\
\text { organisations' training } \\
\text { strategies into the public } \\
\text { system to improve the } \\
\text { impact in the long term? }\end{array}$ & $\begin{array}{l}\text { Primary data: } \\
\text { Interview } \\
\text { Secondary data: Non- } \\
\text { profit organisations' } \\
\text { Report Review }\end{array}$ \\
\hline
\end{tabular}

Own elaboration

Table 2

Participants' profile

\begin{tabular}{llc}
\hline \multicolumn{1}{c}{ Participant } & \multicolumn{1}{c}{ Description } & Number of interviewees \\
\hline Volunteer-Leader & $\begin{array}{l}\text { Non-profit organisation leader. Insight of } \\
\text { management, target audience, objectives, } \\
\text { operations, and outcomes. Two or more years in } \\
\text { the position. }\end{array}$ & 3 \\
\hline Volunteer & $\begin{array}{l}\text { Non-profit organisation volunteer. Have been or } \\
\text { is part of the implementation team and performs } \\
\text { administrative tasks providing empirical } \\
\text { knowledge. One or more years in the position. }\end{array}$ \\
\hline Government Officer & $\begin{array}{l}\text { Minister of Education officer from the Office of } \\
\text { Learning Quality Measurement (UMC) }\end{array}$ \\
\hline
\end{tabular}

Own elaboration 
Table 3

Non-profits' description

\begin{tabular}{cl}
\hline Non-Profit & \multicolumn{1}{c}{ Description } \\
\hline NPA & $\begin{array}{l}\text { Organisation that promotes debate activities for high school and undergraduate students } \\
\text { in Lima. Volunteers interviewed belonged to one of their projects that focus on public } \\
\text { schools' debate workshops. }\end{array}$ \\
\hline NPB & $\begin{array}{l}\text { Organisation that provides supplementary reading, maths and creative workshops after } \\
\text { school, from Monday to Saturday. They target all school levels. To the best of the author's } \\
\text { knowledge, this is one of the biggest NGOs in Peru. }\end{array}$ \\
\hline NPC & $\begin{array}{l}\text { Organisation with operations across the country and in LATAM. In Peru, their main } \\
\text { influence is in Lima, implementing maths and diverse creative workshops once a week in } \\
\text { public schools. They target all school levels and are one of the biggest educational NGOs } \\
\text { in the country. }\end{array}$ \\
\end{tabular}

Own elaboration

The interviews were held in Lima, in Spanish, using an online video platform, and recorded for further analysis, with accepted consent. As for secondary data, the study includes non-profits' reports of up to five years, including impact and financial information. The interview questions were modified according to the participants' profiles and classified into three sections based on the research questions. The data was later analysed based on each section. For the first one, the main variables considered were the motivation of the non-profit to operate in the context, and the characteristics of the vulnerable areas and the public schools where they operate. The aim was to identify each of the variables of the FEQ model. The second research question, it was examined each of the skills listed on the OECD model, selecting the ones the participants either literally mentioned in the interviews or described in the activities. As for the last research question, the variables considered were the methodology per organisation, the resources needed for their activities and how their methodologies disrupt from the ones in the public schools where they operate. The results compare the responses searching for similarities and divergent ideas. The research analyses the discourse of the interviewees regarding non-profits as change actors.

\section{Limitations}

The study was executed during the COVID-19 pandemic, which provided a particular context. The economic and social impact of the pandemic might have affected the participants' mental wellbeing, increasing the bias of their responses. Furthermore, education migrated to digital platforms, adding technological accessibility and learning challenges to teachers. This led to non-profits distancing from them and decreasing opportunities to include teachers in this study, narrowing the scope. This applies to government officers 
too, as some experienced a rise in responsibilities and became less available for interviews. Likewise, the data collected consigns pre-pandemic times. The participants were requested to reply based on their experience from 2019 and before. Moreover, not all non-profits held reports that could apply to soft skills. The reports received showed mainly the numbers of years working, number of beneficiaries and volunteers, and a description of the workshops implemented. Little measurement of the impact on the students has been performed, including soft skills.

\section{FINDINGS}

\section{Quality in education}

Following the first research question, the participants defined their understanding of a vulnerable area and the attributes provided to public schools in these areas. Interviewees related vulnerability with low income and dysfunctional families. In some households, parents hold only high school level education, they are single parents, or could exhibit domestic violence. The latter affects students' mental health, particularly their self-esteem and self-confidence. Some parents could have long workdays, leaving less time to support their children's education, causing weak relationships between schools and parents. These variables endure poverty, maintaining a cycle where children could achieve the same educational level as their parents, linked to underpaid jobs and, on a wider image, discouraging social mobility.

Participants agreed that public schools target cognitive skills leaving aside soft skills, illustrated by teachers who use techniques that neglect the fostering of students' critical analysis and creativity. This is due to a tight curriculum that leaves less time for different activities, failing to add teaching approaches that contribute to educating students as future citizens. Although some teachers are encouraging, others lack training and follow traditional methods, deterring innovation that is especially important in new generations. Moreover, spaces such as cultural centres and libraries are scarce. Despite the lack of resources and management, interviewees affirm that the schools partnered with non-profits differ in their management style, characterised for their partnerships, with principals and teachers motivated to complement the educational experience with alternative sources.

Some public schools differ from the rest. JEC and High-Performance Colleges (COAR in Spanish) are programmes developed by the government that suggest a change of focus towards socioemotional skills, but these have not become widespread yet.

\section{Non-profits and soft skills}

Regarding the second research question, non-profits were assessed based on the socioemotional skills they target directly or indirectly. These organisations shared 
similarities in their objectives; NPA seeks to empower students, NPB aims to cultivate students with bigger aspirations, and NPC pursues developing a social impact within a personal impact. Table 1 presents a detailed profile of the organisations, and while they differ in scope, they perceive themselves as spaces for creativity, innovation, and hope for their students. The number of beneficiaries is unclear in NPC but they operate in schools of minimum 1000 students, and they invite the entire school's population to their workshops, indicating an exponential number.

Table 4

Characteristics of the non-profits' impact 2019

\begin{tabular}{llll}
\hline Variables & NPA & NPB & NPC \\
\hline Year foundation (aprox) & 2012 & 2004 & 2009 \\
N. ${ }^{\circ}$ Schools (2019) & 5 & 3 & 9 \\
Cities (2019) & 1 & 1 & 4 \\
Beneficiaries average per year (2019) & $\sim 180$ & $\sim 300$ & unknown \\
Age range & $13-17$ years-old & $5-15$ years-old & 6-17 years-old \\
Volunteer average 2019 & $\sim 70$ & unknown & $\sim 1000$ \\
\hline
\end{tabular}

Own elaboration

The value of these non-profits relies on the comprehensive focus they provide to their workshops. They target a soft side neglected in most public schools, addressing self-esteem, ethical values, and soft skills, usually improving students' grades. A similarity among these organisations is the reinforcement of maths and reading in their workshops, but they also seek improvements in effective communication and self-confidence, "awakening talents", and sometimes, influencing career decisions.

The interviewees affirm that some of their beneficiaries improve family and social relationships. Their beneficiaries become agents of change with their parents and schools, impacting the community. In the long-term, they tend to return their learnings to their surroundings, evolving into responsible citizens with their communities, and some of them volunteering with these organisations after leaving schools, creating a cycle. This connotes that these organisations raise social awareness between volunteers, beneficiaries, and communities. 
Table 5

Soft skills' impact

\begin{tabular}{|c|c|c|c|c|c|c|c|}
\hline Variable / Participant code & VL1 & VL2 & VL3 & V1 & V2 & V3 & G01 \\
\hline Task Performance & $x$ & $x$ & $x$ & & $x$ & $x$ & \\
\hline Self-Control & $x$ & $x$ & & & & & \\
\hline Responsibility & $x$ & $x$ & & & $x$ & $x$ & \\
\hline Persistance & $x$ & $x$ & & & $x$ & $x$ & \\
\hline Emotional Regulation & & $x$ & & & $x$ & $x$ & \\
\hline Stress Resistance & & & & & $x$ & & \\
\hline \multicolumn{8}{|l|}{ Optimism } \\
\hline Emotional Control & & $x$ & & & $x$ & $x$ & \\
\hline Collaboration & $x$ & $x$ & $x$ & $x$ & $x$ & $x$ & $x$ \\
\hline Empathy & & $x$ & & & $x$ & $x$ & $x$ \\
\hline Trust & & & & & $x$ & & \\
\hline Co-operation & $x$ & $x$ & & $x$ & $x$ & $x$ & \\
\hline Open-mindedness & $x$ & & & $x$ & & & \\
\hline \multicolumn{8}{|l|}{ Tolerance } \\
\hline Curiosity & $x$ & & & $x$ & & & \\
\hline Creativity & $x$ & & & & & & \\
\hline Engaging with Others & $x$ & $x$ & & $x$ & & $x$ & \\
\hline Sociability & $x$ & $x$ & & $x$ & & $x$ & \\
\hline Assertiveness & $x$ & $x$ & & $x$ & & $x$ & \\
\hline \multicolumn{8}{|l|}{ Energy } \\
\hline Additional Indicies & $x$ & $x$ & & & $x$ & $x$ & \\
\hline Achievement Motivation & $x$ & $x$ & & & $x$ & $x$ & \\
\hline Self-Efficacy & & & $x$ & & & $x$ & \\
\hline
\end{tabular}

Own elaboration

Analysing the interviews with the OECD's model, the skills addressed by each organisation are described in Table 4. Collaboration and Task Performance were the skills mentioned by most participants; empathy and co-operation were identified as essential in their activities. Open-mindedness is a category referred to by NPA, which is dedicated to debate workshops. These include their students sharing experiences with students from different institutions, sometimes private schools, which differ from the other organisations. The NPA's leader affirmed that the collaborative nature of the debate methodology forces students to cooperate towards a common objective. 
NPB distinguishes with daily workshops and Emotional Regulation development. They assert that this frequency allows them to target emotional control as they possess more time to build a trusting bond with their students, helping them manage their emotions. NPC participants featured in Self-Efficacy, which relates to a person's belief in their capacity to accomplish an objective because they encourage students to believe in their dreams. They declare that soft skills need to be complemented with abilities that can transform their dreams into reality.

Table 5 only reflects the explicit participants' responses that could be linked to a specific skill, but their impact is not limited to these skills only. Interviewees agreed they influence self-esteem and self-confidence but also cultivate values such as solidarity, respect, empathy, responsibility, teamwork, and assertive communication, which provides the beneficiaries with a wider perspective of their context. Non-profits become safe places of belonging where students are listened to, so they can develop their critical sense and analytic capacity, skills that would allow them to improve their opportunities in the future.

\section{Replicability}

Following the third research question, the feasibility of adapting non-profits' training strategies into the public system is assessed based on resources and methodological differences. A continuous lack of resources decreases the projects' impact, affecting their stability and measurement, which can be either financial issues or human resources. Volunteers are key for implementation and administrative duties. Organisations agree that volunteers are characterised by vocation, collaboration, passion and motivation to reinvent themselves. They function as educators with a new approach, more open to change than traditional teachers, meaning they hold a different technical or specific knowledge. This knowledge can sometimes be taught by the organisations, but the most important feature in candidates are their soft skills and values. As for logistical resources to implement the workshops, tailored material or session guidelines are needed, and in less relevance, technical equipment.

The methodologies exhibited by non-profits share a common ground; two of them include pedagogues for technical support, pursuing comprehensive learnings and structured sessions. These organisations offer creativity, artistic and sportive workshops as extracurricular activities, using playful and concrete techniques. The former means that they provide spaces for students to participate and discover concepts within an interactive environment, aiming to develop significant learning with concrete materials, so the students can physically experience and learn by playing and investigating. This becomes a customised methodology that leads students to create their own concepts. 
In contrast, public schools are unlikely to apply these concrete methodologies due to a lack of time. Designing materials involves time that teachers might not have as they can perform more than one class on a day or have an extra job. Participants maintain that teaching in public schools becomes an exercise by heart rather than understanding and questioning, and experiences with materials that students can manipulate are scarce; learning by doing is not encouraged. In their perspective, teachers appear to be pressured by a tight curriculum and bureaucratic processes; although they might be trained in this methodology, preparing materials for so many students can be overwhelming, and they prioritize the curriculum's cognitive side. This can cause teachers to discourage participation and avoid feedback, which is perceived as a deterrent of critical capacity and a strong focus on cognitive knowledge, leaving aside socioemotional skills and ethical values. Teachers are unable to provide a holistic perspective due to the pressure of accomplishing their planned schedule. Against public schools who are responsible for comprehensive education, non-profits can focus on an overlooked side.

The interviewees agreed that private schools in the areas also struggle to provide quality education, but the ones that exceed are supported by psychologists and extracurricular workshops. For instance, the Tutoring hour is focused on students' development as a space to listen to their ideas and concerns, allowing them to create projects that foster significant learning. In public schools, this hour is considered as additional time for other courses, not providing spaces for them to express their ideas and design projects or, if implementing projects, these would have been enforced by the teachers.

Due to structural and systematic concerns, soft skills might be neglected in public schools. One of the interviewees declared that even teachers might need to develop their socioemotional skills. As part of the reforms, the government is encouraging a qualitative perspective and training teachers, so they focus on the process of the learning experience and not only the final product. However, the path to improvement is still long. The concrete methodologies used by the non-profits might be applicable if teachers are released from some duties and received further training.

\section{CONCLUSIONS}

\section{Quality in education in Peru}

Analysing the interviews with the FEQ model, a profile of public education in vulnerable areas in Lima arises. The Context is characterised by low development opportunities, enduring a poverty cycle. Public schools offer two or three shifts per day, shortening school hours, forcing the prioritization of core courses, neglecting artistic or sportive workshops. Some institutions lack administrative and psychological support, which hinders a comprehensive education and a customised learning experience. In this 
scenario, non-profits become an opportunity, fostering spaces that cultivate soft skills and values through workshops with a strong ethical perspective, and, being a supplement to schools, their scope and frequency are lower, but this allows them to supervise on a case-by-case basis, customising the workshops, developing different skills.

The Learner's Characteristics features dysfunctional families that might affect the students' mental wellbeing. Parents with long workdays are more likely to disengage from school governance, leading to a weak school-parent relationship. Students are also less inclined to trust the school or their peers, which can impact their attainment. One of the interviewees stated that in some schools, students will take their bags when leaving the classroom in the breaks as they distrust their peers. This is a serious concern as students share daily experiences for long periods, connoting a lack of inter and intrapersonal skills, as well as values and ethics. This context challenges skills development, which appear more plausible in private schools.

Teachers, key in the Enabling Inputs, are pressured from different perspectives. They hold a low reputation from society, being under-qualified, old-fashioned, and centred on cognitive teaching. The central government stresses them with rigid assessments for promotions or to maintain their position, and schools demand them to exceed the stated curricula. The low salaries and negative perspective transform it into an unattractive career, leaving the average teacher age over 40-years-old (Saavedra \& Gutierrez, 2020). Although the government is changing their training focus towards soft skills, the number of duties and reduced time might prevent teachers from implementing innovative methodological changes.

This situation impacts Teaching and Learning as classes seem to be teachercentred rather than student-centred. The participants indicated that classes are planned and executed without the students' views, and participation or feedback is not encouraged. Playful and innovative methodologies are limited, and techniques seem repetitive, deterring students from experimenting, analysing, and defining concepts from their experience. Interviewees agreed that students are mostly told how to do things instead of developing critical analysis. Although a regular class holds between 24-30 students each, teachers tend to manage more than one class, so it is difficult to oversee case-bycase. An important difference between private and public institutions is the extra hours, which the former use for extracurricular activities. The Minister is implementing projects such as JEC and COAR, which provide extra time, administrative support, and additional activities resembling private management. They are especially important for the value provided to socioemotional skills; although these are not widespread yet, they illustrate the importance the government grants to these skills (JEC, n.d; MINEDU, n.d.b).

These variables represent fragile inputs for successful Outcomes. In maths and reading international assessments, Peru lands among the lowest performers in the 
world. These are measurable indicators that connote the reality of soft skills development as a real concern, as these might be in more critical status and are not being assessed. As mentioned, soft skills can predict educational attainment, earning and risky behaviours (Cunha \& Heckman, 2008; Zamarro et al., 2016). Peruvians who continue their education at higher levels are most valued in the labour market, therefore, have more opportunities, but only around $48 \%$ of the population continues studying after school (MINEDU, 2019). In the long-term, skills can impact national development.

\section{Soft skills development}

Non-profits are not indifferent to the critical context and, directly or indirectly, they address the development of soft skills particularly related to Task Performance and Collaboration. The first one has been related to high educational achievement, low crime tendency, and a healthy lifestyle (Kautz et al., 2014). Collaboration is identified with leadership and motivation in the workplace (Suddleson, 2015). Both categories connote a development of people more empowered to break the poverty cycle. The leader of NPB stated that $67 \%$ of their students have continued their education in universities or technical institutions, against the average of $2 \%$ in the area.

The OECD's model also provides a difference of skills per age. The non-profits participating in this research target varying ages, while NPB and NPC include pedagogues in their activities designed to be accurate per age; NPA works exclusively with teenagers. The model illustrated the development of cognitive skills at younger ages, while soft skills become more relevant from adolescence onwards. NPA reinforces Collaboration and Open-mindedness skills, particularly cooperation. NPB builds relationships with their beneficiaries and targets Emotional Regulation skills, which seems stronger than in other non-profits due to their daily frequency. NPC cultivated Self-Efficacy as they aim to improve self-esteem. Although short-term, these organisations perceived their impact as positive, visible on the improvement of grades and their students' change of attitude.

Schools partnered with these organisations differentiate with an ambition to improve their students' experience. This signifies that they might perform more effective management and are more open to implementing new methodologies, providing their students with an advantage among other public schools, even before the non-profits implementation. This is also positive for parents as, with reduced time for supervision, low educational level, and low income, they hold fewer alternatives to foster their children's soft skills.

Students in other public schools, that not benefit from these partnerships and management styles, need to straighten their opportunities. Public schools prioritise cognitive skills and leave aside soft skills due to structural and systematic issues. The government seeks to fulfil a curriculum aiming to develop citizens who contribute to the 
nation, training teachers on soft skills, but providing them little time for methodological changes. Soft skills appear important on policies, but it does not seem to be the reality in the classrooms, remaining blurry in national policies. Teacher-centred environments provide fewer opportunities to develop a critical opinion. In this sense, education should aim to develop more than cognitive learnings, as it would empower students to become successful women and men in society (Freire, 1972).

\section{DISCUSSION}

This study aimed was to examine the enhancement of soft skills in public education in Peru through analysing non-profit organisations' techniques at the school level, determined as a gap in the literature review.

Objective 1. To understand how the quality of education in public schools in Peru assures the development of soft skills.

The government has acknowledged the main concerns, and it is addressing them with training and tightening standards, seeking a higher quality. Despite being an important actor, the central government which designs and enforces the policies is not the only one involved in quality; other factors and stakeholders should be considered too. Further analysis that is out of this reaserch's scope is required to understand this process, but a glimpse of critical areas has been provided already.

The government is implementing initiatives that directly or indirectly encourage soft skills development, such as JEC and COAR schools, teachers' training, and curriculum changes, which would have a visible effect in the upcoming years and set a precedent for educative policies. However, at the public-school level, changes translate into more responsibilities for institutions, especially for teachers. This means that methodologies centre on cognitive skills, easier to assess and measure, leaving aside soft skills.

Teachers, being key actors in the process, are overwhelmed with multiple responsibilities. Their negative reputation in society appears to be the result of a long-lasting problem hatched throughout decades, causing fewer applications for this career and increasing the age. Hence, the profession does not renew its workforce, which creates an innovation concern. Alongside the school management, this influences the methodologies applied, which according to the interviews, appear to be teacher-centred rather than student-centred, deterring soft skills. The research concludes that teachers are important influencers between schools and non-profits, as they search for connections that can improve their students' experience. A different approach is needed in public schools' management, so students can experiment and participate to reach significant learning that fosters socioemotional skills. 
Some participants agreed that parents are not involved in school governance as needed. This does not signify they are detached from their children's education but rather from their demands with school performance. The research has mentioned the lack of involvement in parental associations and the relevance provided to reputation rather than outcomes. Educational attainment, as an indicator, becomes less important than the institutions' reputations. This is a sign of how society values education and the concept parents hold of quality.

Mental health is another topic that arises. This is left aside as much as soft skills, which is alarming for development. Among the characteristics of vulnerable areas, dysfunctional families and domestic violence are a reality in some households, affecting the students' mental health but being overseen in public schools. Many times schools lack psychological resources to support students. Non-profits provide a space for beneficiaries to enforce their self-esteem and self-confidence, helping a psychological side too. These organisations also highlight the importance of soft skills, values, and ethics, as students in vulnerable areas are most likely to confront unfavourable environments to develop soft skills and ethical values. Besides, non-profits use these terms as interchangeable ones, which might affect measurement attempts.

Objective 2. To explore the potential of non-profit organisations in supporting the development of soft skills in public schools.

This research acknowledges the value of non-profits as driving forces for soft skills enhancement in vulnerable areas. They offer a disruptive space for comprehensive learning, with a strong focus on the soft side of the beneficiaries. Despite their short scope, they can provide an individual and customised experience, which appears to impact the short and medium-term, particularly with senior students, guiding their career decisions. According to studies, Peruvians in vulnerable areas in Lima are less likely to pursue higher education levels (CPI, 2019), which reinforces the relevance of these organisations.

As mentioned, these organisations develop a range of skills, focusing on the ones related to Collaboration and Task Performance. Likewise, they are supporting public education in the development of citizens more skilled to overcome life challenges. Vulnerable areas are spaces with more probabilities for risky behaviours, explaining the importance of soft skills, ethics and values in non-profits. Soft skills, then, contribute to discontinuing the poverty cycle, raising the educational level, personal well-being and reducing crime tendencies. This impact reaches families and communities, which in the long-term, enhances the development of these areas.

These non-profits have several years of implementation and continue their work thanks to donations and partnerships. Some of these are part of companies' social 
responsibility activities and other organisations, which has not influenced the nonprofits' objectives. This is important as a constraint with NGOs is the hidden agenda some donors can have, but which was not present in these case studies. Nevertheless, their impact still holds a low scope and might struggle to maintain this in the long-term due to resources. Despite being one of the biggest NGOs in education in Peru and with over one thousand volunteers, NPC only reached ten schools in 2019 across the country. This connotes the difficulty of replicability in the public sector.

Regarding the methodology, an important difference between public schools and non-profits is the playful and concrete techniques applied by the latter. This involves preparing materials so students learn by doing, interacting and constructing a concept, which could signify additional time for preparation and implementation. This is challenging to apply in public schools as teachers possess less time and more responsibilities than volunteers. While a volunteer oversees one workshop, teachers can execute many classes in a day. Teachers might be aware of this drawback, but they are restricted with responsibilities and time, which means more training, hours and resources could be needed to execute innovative and diverse methodologies to foster soft skills. Public schools such as JEC offer an alternative for this gap, but this would imply a considerable increment in public investment and management, which is out of the scope of this study. In this context, non-profits' techniques might be too ambitious for the public sector, and changes in the educational system and schools' management would be needed to consider them. In the meantime, additional support, training, and resources would allow non-profits to improve and expand their operations.

\section{LIMITATIONS AND SUGGESTIONS}

This research was achieved throughout the COVID-19 pandemic, which added considerable limitations to the process. Albeit non-profit leaders were supportive in contacting teachers from public schools, they were unreachable due to the increment in their responsibilities, missing their contribution. This signified a gap in their perspective of soft skills in public schools. A similar issue arose with government officers, which is the reason for not including more participants in this group. To complement these drawbacks, an extensive literature review was considered.

The conclusions exhibit a critical context for soft skills development in public institutions. Although non-profits are addressing this gap, further research should consider assessing their impact in the long-term, especially analysing crime tendency, educational attainment, earning and wellbeing of their beneficiaries, compared to a non-beneficiaries sample from the same areas. Their workshops share similarities to studies performed in developed countries in vulnerable areas, holding positive results in beneficiaries' earnings, non-cognitive skills, educational attainment, and a slight influence in crime 
tendency (Kautz et al., 2014). Moreover, further research can assess the impact in the local communities and how the schools' management influence on skills development.

As long as public schools prioritise cognitive skills and minimise socioemotional ones, there will be a breach to achieve comprehensive education.

\section{REFERENCES}

Aprendo Contigo (n.d.). Quienes somos [About us]. Aprendo contigo [I Learn with You] https://www.aprendocontigo.org/quienes-somos/

Banks, N., Hulme, D., \& Edwards, M. (2015). NGOs, States, and Donors Revisited: Still Too Close for Comfort? World Development, 66, 707-718. https://doi.org/10.1016/j. worlddev.2014.09.028

Bebbington, A. (1997). New States, New NGOs? Crises and Transitions among Rural Development NGOs in the Andean Region. World Development, 25(11), 1755-1765. https://doi.org/10.1016/S0305-750X(97)00066-1

Castro, J.F., Yaqmada, G., \& Arias, O. (2016). Higher Education Decisions in Peru: On the Role of Financial Constraints, Skills, and Family Background. Higher Education, 72(4), 457-486. http://doi.org/10.1007/s10734-016-0040-x

Cortina, R. (2016). How to Improve Quality Education for Indigenous Children in Latin America. In R. Cortina (Ed.), Indigenous Education Policy, Equity, and Intercultural Understanding in Latin America (pp. 3-25). Palgrave Macmillan US. https://doi. org/10.1057/978-1-137-59532-4_1

CPI (2019). Perú: Población 2019 [Peru: 2019 Population] (Market Report No 4). Compañía Peruana de Estudios de Mercados y Opinión Pública [Compañía Peruana de Estudios de Mercados y Opinión Pública] http://cpi.pe/images/upload/ paginaweb/archivo/26/mr_poblacional_peru_201905.pdf

Cueto, S. (2016). Innovación y calidad en educación en América Latina [Innovation and quality in Latin America]. ILAIPP \& GRADE. https://www.grade.org.pe/wp-content/ uploads/ILAIPPGRADE_innovcalEdu.pdf

Cunha, F., \& Heckman, J. J. (2008). Formulating, Identifying and Estimating the Technology of Cognitive and Noncognitive Skill Formation. Journal of Human Resources, 43(4), 738-782. https://doi.org/10.1353/jhr.2008.0019

Darcourt, A., Ramos, S., Moreano, G., \& Hernández, W. (2020). Why Do Peruvian School Students Choose Science and Technology Careers? In K.Villalba-Condori, A. Aduríz-Bravo, J. Lavonen, L. Wong, \& T. Wang (Eds.), Education and Technology 
in Sciences Communications in Computer and Information Science (pp. 158-173). https://doi.org/10.1007/978-3-030-45344-2_13

Di Gropello, E. (2006). A Comparative Analysis of School-Based Management in Central America. (World Bank Working Paper No. 72). The World Bank. http://hdl.handle. net/10986/6978

El Comercio (2014). Apafas: ¿A dónde va el dinero que los padres pagan? [Apafas: Where does the money parents pay go?]. El Comercio. https://elcomercio.pe/lima/ apafas-dinero-padres-pagan-295446-noticia/

Freire, P. (1972). Pedagogy of the oppressed. Herder and Herder.

Glewwe, P., \& Kremer, M. (2006). Chapter 16. Schools, Teachers, and Education Outcomes in Developing Countries. In E. Hanushek, F. Welch (Eds.), Handbook of the Economics of Education: Vol 2 (pp. 945-1017). Elsevier B.V. https://doi.org/10.1016/ S1574-0692(06)02016-2

Hanushek, E. A., \& Woessmann, L. (2015). The Knowledge Capital of Nations: Education and the Economics of Growth. MIT press.

Hanushek, E. A., \& Woessmann, L. (2007). The Role of Education Quality for Economic Growth. The World Bank. http://hdl.handle.net/10986/7154

Humphries, J. E., \& Kosse, F. (2017). On the Interpretation of Non-Cognitive Skills - What is Being Measured and why it Matters. Journal of Economic Behavior \& Organization, 136, 174-185. https://doi.org/10.1016/j.jebo.2017.02.001

Hynsjö, D., \& Damon, A. (2016). Bilingual Education in Peru: Evidence on how QuechuaMedium Education Affects Indigenous Children's Academic Achievement. Economics of Education Review, 53, 116-132. https://doi.org/10.1016/j. econedurev.2016.05.006

INEI (2019a). Producción y empleo informal en el Perú [Informal production and employment in Peru]. Instituto Nacional de Estadística e Informática [Statistics and Informatic National Institute]. https://www.inei.gob.pe/media/MenuRecursivo/ publicaciones_digitales/Est/Lib1701/libro.pdf.

INEI (2019b). Indicadores de Educación por departamento 2008-2018 [Education Indicators by department 2008-2018]. Instituto Nacional de Estadística e Informática [Statistics and Informatic National Institute]. https://www.inei.gob.pe/media/ MenuRecursivo/publicaciones_digitales/Est/Lib1680/

Jagannathan, R., Camasso, M. J., \& Delacalle, M. (2019). Promoting Cognitive and Soft Skills Acquisition in a Disadvantaged Public School System: Evidence from the 
Nurture thru Nature Randomized Experiment. Economics of Education Review, 70, 173-191. https://doi.org/10.1016/j.econedurev.2019.04.005

James, P., Nadarajah, Y., Haive, K., Stead, V., Age, A., Annear, P., \& Yomba, J. (2012). Informal Economies and Community Livelihoods. In P. James, Y. Nadarajah, K. Haive, \& V. Stead (Eds.), Sustainable Communities, Sustainable Development: Other Paths for Papua New Guinea (pp. 216-246). University of Hawaii Press. https://doi. org/10.21313/hawaii/9780824835880.003.0007

Jayaram S., \& Engmann M. (2017). Diagnosing the Skill Gap. In Jayaram S., Munge W., Adamson B., Sorrell D. and Jain N. (Eds.), Bridging the Skills Gap. Technical and Vocational Education and Training: Issues, Concerns and Prospects (pp. 1-14). Springer. https://doi.org/10.1007/978-3-319-49485-2_1

JEC (n.d.). Componentes del modelo educativo de la JEC [Components of the educational model of the JEC]. Jornada Escolar Completa [Full Day School] http://jec. perueduca.pe/?page_id $=4912$

Kankaraš M., \& Suarez-Alvarez J. (2019). Assessment Framework of the OECD Study on Social and Emotional Skills. (OECD Education Working Papers No. 207). OECD. https://doi.org/10.1787/5007adef-en

Kautz, T., Heckman, J. J., Diris, R., Ter Weel, B. \& Borghans, L. (2014). Fostering and Measuring Skills: Improving Cognitive and Non-cognitive Skills to Promote Lifetime Success. National Bureau of Economic Research, 0898-2937. https://doi. org/10.3386/w20749

Kerstetter, K. (2016). A Different Kind of Discipline: Social Reproduction and the Transmission of Non-cognitive Skills at an Urban Charter School. Sociological Inquiry, 86(4), 512-539. https://doi.org/10.1111/soin.12128

Lleras, C. (2008). Do Skills and Behaviors in High School Matter? The Contribution of Noncognitive Factors in Explaining Differences in Educational Attainment and Earnings. Social Science Research, 37(3), 888-902. https://doi.org/10.1016/j. ssresearch.2008.03.004

Marcos, M., \& Vásquez, M. C. (2018). Tipología y caracterización de las escuelas privadas en el Perú [Typology and characterization of private schools in Peru]. (Serie Estudios Breves [Brief Studies Series] N. ${ }^{\circ}$ 3). Ministerio de Educación (MINEDU) [Ministry of Education]. http://umc.minedu.gob.pe/wp-content/ uploads/2019/01/EB03.pdf

McCrae, R., \& A. Terracciano (2005). Universal Features of Personality Traits from the Observer's Perspective: Data from 50 cultures. Journal of Personality and Social Psychology, 88, 547-561. https://doi.org/10.1037/0022-3514.88.3.547 
MIMP (n.d). Diagnóstico situacional de organizaciones de voluntariado [Situational diagnosis of volunteer organizations]. Ministerio de la Mujer y Poblaciones Vulnerables (MIMP) [Ministry of Women and Vulnerable Populations]. https://www.mimp. gob.pe/sinavol/files/INFORMEBREVE-CONSOLIDADO7REGIONES.pdf

MINEDU (2016). Programa curricular de educación secundaria. [Secondary Education Curriculum Program]. Ministerio de Educación (MINEDU) [Ministry of Education]. http://www.minedu.gob.pe/curriculo/pdf/programa-curricular-educacionsecundaria.pdf

MINEDU (2017). Currículo nacional de la educación básica. [National Curriculum of Basic Education]. Ministerio de Educación (MINEDU) [Ministry of Education]. http:// www.minedu.gob.pe/curriculo/pdf/curriculo-nacional-de-la-educacion-basica. pdf

MINEDU (2018). Perú: ¿cómo vamos en educación? [Peru: how are we doing in education?]. Unidad de Estadística [Statistics Unit]. Ministerio de Educación (MINEDU) [Ministry of Education]. https://siteal.iiep.unesco.org/sites/default/files/sit_ accion_files/peru_como_vamos_en_educacion._2018.pdf

MINEDU (n.d.a) Evaluación Docente [Teachers assessment]. Ministerio de Educación (MINEDU) [Ministry of Education]. http://evaluaciondocente.perueduca.pe/ evaluacion-docente/.

MINEDU (n.d.b). Colegios de Alto Rendimiento [High Performance Schools]. Ministerio de Educación (MINEDU) [Ministry of Education]. http://www.minedu.gob.pe/coar/ index.php\#admision.

Mizala, A., \& Ñopo, H. (2016). Measuring the Relative Pay of School Teachers in Latin America 1997-2007. International Journal of Educational Development, 47, 20-32. https://doi.org/10.1016/j.ijedudev.2015.11.014

Namuddu K., Jain N., \& Adamson B. (2017). Systemic Curricular Change. In S. Jayaram, W. Munge, B. Adamson, D. Sorrell \& N. Jain N (Eds.), Bridging the Skills Gap. Technical and Vocational Education and Training: Issues, Concerns and Prospects (pp. 55-75). Springer. https://doi.org /10.1007/978-3-319-49485-2_4

Nichols, M. (2017). Can I Choose to Have Grit? Non-cognitive Skills, Behavior, and School Choice. Journal of School Choice, 11(4), 622-641. https://doi.org/10.1080/1558215 9.2017 .1395636

OECD (2014). PISA 2012 Results in Focus. What 15-year-olds know and what they can do with what they know. OECD Publishing. https://www.oecd.org/pisa/keyfindings/pisa2012-results-overview.pdf 
OECD (2015). OECD Skills Studies: Skills for Social Progress: The Power of Social and Emotional Skills. OECD Publishing. https://www.oecd.org/education/skills-forsocial-progress-9789264226159-en.htm

Oded, G. (2011). Inequality, Human Capital Formation and the Process of Development. National Bureau Of Economic Research. https://doi.org/10.3386/w17058

Osorio, A., Aredo, M., Bonillla, M., Castro, O., Isidro, L., Quintanilla, C., Sabino, C., \& Villavicencio, R. (2018). Report on Mathematics Teacher Preparation in Perú. In: Y. Baldin \& U. Malaspina (Eds.), Mathematics Teacher Education in the Andean Region and Paraguay (pp. 75-103). Springer International Publishing. https://doi. org/10.1007/978-3-319-97544-3_4

Portocarrero, F., Sanborn, C., Cueva, H., \& Millán, A. (2002). Más allá del individualismo: el tercer sector en el Perú [Beyond individualism: the third sector in Peru]. Universidad del Pacífico.

Primi, R., Zanon, C., Santos, D., De Fruyt, F., \& John, O. P. (2016). Anchoring Vignettes: Can They Make Adolescent Self-Reports of Social-Emotional Skills More Reliable, Discriminant, and Criterion-Valid? European Journal of Psychological Assessment, 32(1), 39-51. https://doi.org/10.1027/1015-5759/a000336

Rose, P. (2009). NGO Provision of Basic Education: Alternative or Complementary Service Delivery to Support Access to the Excluded? Compare, 39(2), 219-233. https://doi. org/10.1080/03057920902750475

Saavedra, J., \& Gutierrez, M. (2020). Peru: A Wholesale Reform Fueled by an Obsession with Learning and Equity. In: F. Reimers (Ed.), Audacious Education Purposes (pp. 153-180). https://doi.org/10.1007/978-3-030-41882-3

Sánchez, A., \& Favara, M. (2019). Consequences of Teenage Childbearing in Peru: Is the Extended-School-Hour-Program an Effective Policy Instrument To Prevent Teenage Pregnancy? (Working Paper Young Lives N. ${ }^{\circ}$ 185). Young Lives. https:// www.younglives.org.uk/content/consequences-teenage-childbearing-peruextended-school-day-reform-effective-policy

Schleicher, A. (2019). PISA 2018: Insights and Interpretations. OECD Publishing. https:// www.oecd.org/pisa/PISA\%202018\%20Insights\%20and\%20Interpretations\%20 FINAL\%20PDF.pdf

Suddleson, H. (2015). Empathy, Attitude, and Other Soft Skills that Translate into Hard Dollars. Air conditioning, heating \& refrigeration news, 256(3).

Tawil, S., Akkari, A., \& Macedo, B. (2012). Beyond the Conceptual Maze: the Notion of Quality in Education. UNESCO Education Research and Foresight, 2, 1-16. 
https://learningportal.iiep.unesco.org/en/library/beyond-the-conceptual -maze-the-notion-of-quality-in-education

UNESCO (2005). Education for All. The Quality Imperative. (Efa Global Monitoring Report 2005). Unesco. https://en.unesco.org/gem-report/report/2005/ education-all-quality-imperative

Walliman, N.S.R. (2011). Research Methods: the Basics. Routledge.

Wang, H., Chu, J., Loyalka, P., Xin, T., Shi, Y., Qu, Q., \& Yang, C. (2016). Can Social-Emotional Learning Reduce School Dropout in Developing Countries? Journal of Policy Analysis and Management, 35(4), 818-847. https://doi.org/10.1002/pam.21915

West, M. R., Kraft, M. A., Finn, A. S., Martin, R. E., Duckworth, A. L., Gabrieli, C. F. O., \& Gabrieli, J. D. E. (2016). Promise and Paradox: Measuring Students' Non-Cognitive Skills and the Impact of Schooling. Educational Evaluation and Policy Analysis, 38(1), 148-170. https://doi.org/10.3102/0162373715597298

World Bank (n. d.). Government Expenditure on Education, Total (\% of GDP). World Bank. https://data.worldbank.org/indicator/SE.XPD.TOTL.GD.ZS

World Bank (2007). Toward High-quality Education in Peru. Standards, Accountability, and Capacity Building. The World Bank. https://digitallibrary.un.org/record /615921? $\ln =$ en

Zamarro, G., Cheng, A., Shakeel, M. \&\& Hitt, C. (2016). Comparing and Validating Measures of Character Skills: Findings from a Nationally Representative Sample. (University of Arkansas Working Paper Series 2016-08). University of Askansas. https:// scholarworks.uark.edu/edrepub/32 


\section{APPENDIX}

\section{Appendix 1. Description of OECD's Social and Emotional Skills}

\begin{tabular}{|c|c|c|}
\hline $\begin{array}{l}\text { "BIG FIVE" } \\
\text { DOMAINS }\end{array}$ & SKILLS & DESCRIPTION \\
\hline \multirow{3}{*}{ 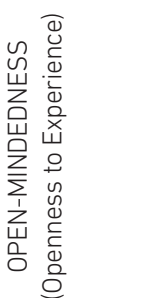 } & CURIOSITY & $\begin{array}{l}\text { Interest in ideas and love of learning, understanding and intellectual } \\
\text { exploration; an inquisitive mind-set. }\end{array}$ \\
\hline & TOLERANCE & $\begin{array}{l}\text { Is open to different points of view, values diversity, is appreciative of } \\
\text { foreign people and cultures. }\end{array}$ \\
\hline & CREATIVITY & $\begin{array}{l}\text { Generating novel ways to do or think about things through exploring, } \\
\text { learning from failure, insight and vision. }\end{array}$ \\
\hline
\end{tabular}

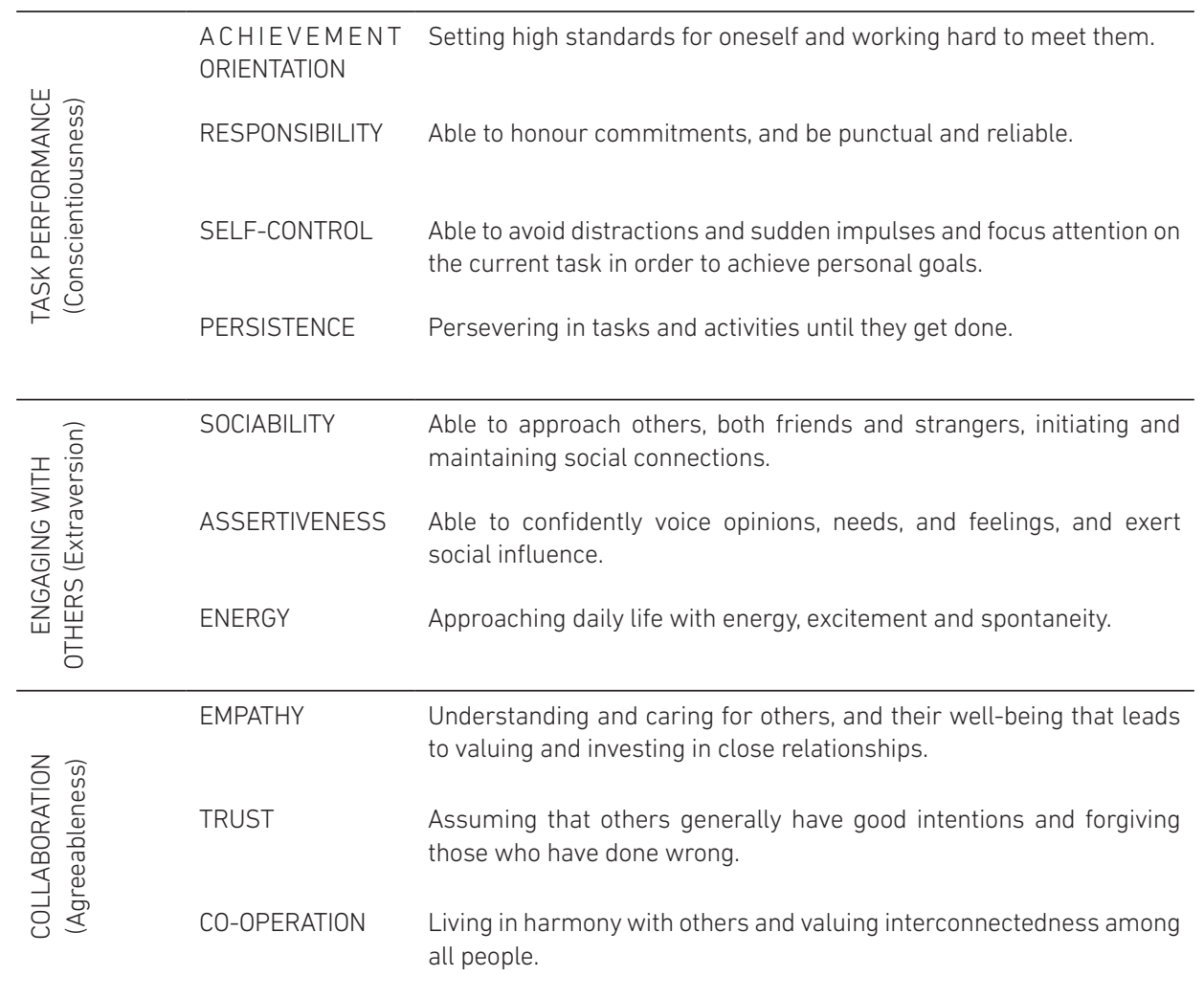


Development of Soft Skills from Out-of-School Experiences in Peru

(continuación)

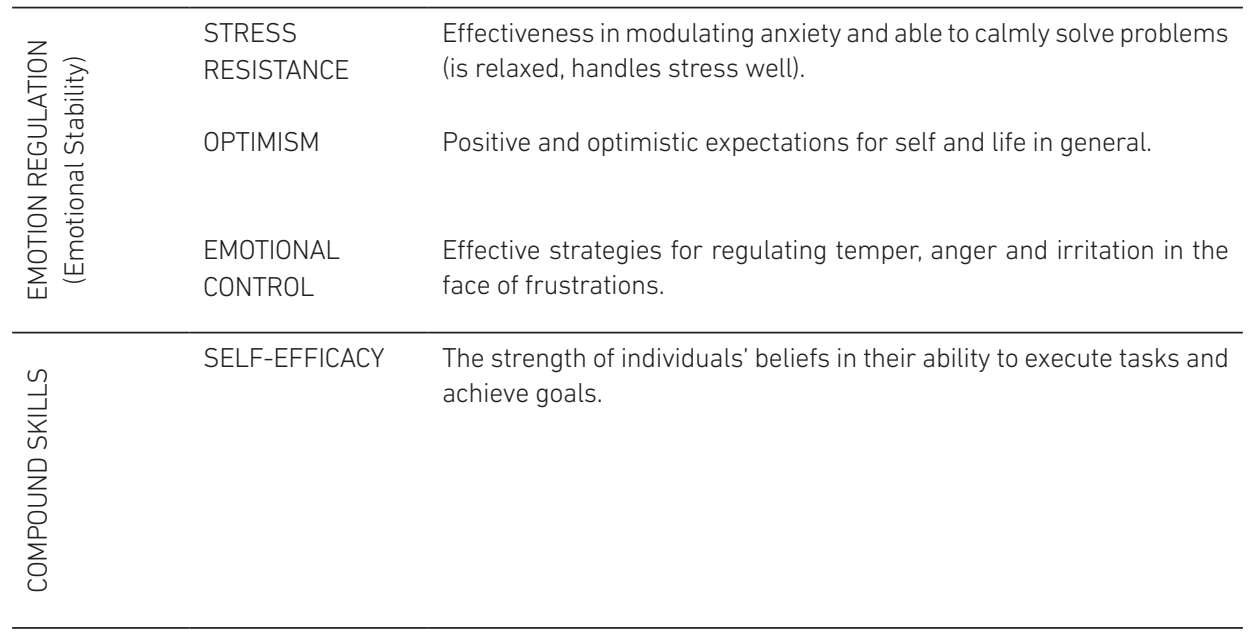

Source: Adapted from Kankaraš, M. and Suarez-Alvarez, J. (2019) 
